\title{
Lipoprotein macroaggregates in bronchoalveolar lavage fluid from patients with diffuse interstitial lung disease: comparison with idiopathic alveolar lipoproteinosis
}

\author{
P L HASLAM, D A HUGHES, A DEWAR, C F A PANTIN \\ From the Cell Biology Unit, Department of Thoracic Medicine, and Department of Electron Microscopy, \\ Cardiothoracic Institute, London
}

\begin{abstract}
Lipoprotein macroaggregates were present in cytocentrifuge preparations of $\frac{T}{O}$ bronchoalveolar lavage fluid from four patients with diffuse lung diseases other than idiopathic alveolar lipoproteinosis. In three patients the primary diagnosis was cryptogenic fibrosing alveolitis and in one sarcoidosis. We confirmed the presence of large multilamellar aggregates of lipoprotein by $\vec{\bullet}$ ultrastructural examination in patients with both interstitial lung disease and idiopathic alveolar $\infty$ lipoproteinosis. The small lamellar bodies and amorphous debris found in idiopathic alveolar 0 lipoproteinosis were rare in the patients with interstitial lung disease. The lavage fluid from patient with interstitial lung disease did not show the substantial alterations in phospholipid composition $\frac{\partial}{0}$ that were seen in lavage fluid in idiopathic alveolar lipoproteinosis. These ultrastructural and biochemical features may help to distinguish idiopathic from other causes of alveolar lipoproteinosis, $\stackrel{\odot}{\unrhd}$ particularly at an early stage, when differential diagnosis may be difficult.
\end{abstract}

Small volume segmental bronchoalveolar lavage via the fibreoptic bronchoscope is a routine part of the preliminary investigation of patients with diffuse lung diseases in many centres. ${ }^{1-3}$ The finding of lipoprotein in the lavage fluid, in amounts sufficient to cause a milky gross appearance ${ }^{\prime}$ and detectable by light microscopy, has been reported as diagnostic of the rare disorder idiopathic alveolar lipoproteinosis, ${ }^{4}$ a condition characterised by accumulations of phospholipids, cholesterol, free fatty acids, and proteins in the alveolar spaces. ${ }^{5-7}$ The usual presenting symptoms are progressive breathlessness, cough, and a diffuse and irregular fine granular mottling on the chest radiograph. ${ }^{589}$ With these non-specific features, idiopathic alveolar lipoproteinosis is often initially misdiagnosed as another lung disease, such as sarcoidosis. ${ }^{1011}$

During routine cytological screening of lavage samples from patients with widespread radiographic

Address for reprints: Dr P L Haslam, Cell Biology Unit, Department of Cardiothoracic Surgery, Cardiothoracic Institute, London SW3 $6 \mathrm{HP}$.

Accepted 16 September 1987 shadows due to various causes, we have occasionally observed macroaggregates of lipoprotein in patients $\bar{\partial}$ without idiopathic alveolar lipoproteinosis. Further investigation confirmed the diagnosis of interstitial $\stackrel{\times}{-}$ lung disease, suggesting that the lipoprotein aggregates were a secondary feature. We have explored the relevance of this rare appearance by relating the clinical features of these patients too ultrastructural and biochemical findings.

\section{Methods}

PATIENTS

Bronchoalveolar lavage was undertaken as previously reported $^{12}$ in 718 patients undergoing routine inves- 0 tigation of widespread shadows on the chesto

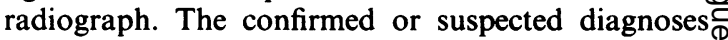
were cryptogenic fibrosing alveolitis (243), sarcoidosis $\stackrel{\circ}{?}$ (273), and various other lung diseases (202), including 0 those associated with inhaled inorganic or organic $\bar{P}$ dusts, pulmonary haemosiderosis, and histiocytosis $\mathrm{X}$. Four hundred and fifty patients were untreated at the time of lavage, and the remainder were having pred- -2 nisolone, with or without cyclophosphamide. None of 
these patients was initially diagnosed as having idiopathic alveolar lipoproteinosis. In five patients lipoprotein aggregates were observed during routine cytological screening of the lavage samples. Details of these patients are given in table 1 .

Ultrastructural and biochemical comparisons were made with lavage material obtained from four patients with idiopathic alveolar lipoproteinosis undergoing therapeutic whole lung lavage. ${ }^{10}$ Sterile $0.9 \%$ sodium chloride at $37^{\circ} \mathrm{C}$, buffered to neutral $\mathrm{pH}$, was used for both lavage procedures.

\section{METHODS}

Bronchoalveolar lavage fluid cytology

The cells and sedimentable material were prepared for light microscopy ${ }^{13} \mathrm{~A}$ differential count of 300-500 nucleated cells was performed by selecting random fields, after which the entire preparation was scanned to record any other features present. Where large globules of acellular material suspected to be lipoprotein were observed, spare air dried cytocentrifuge preparations were treated with other stains to aid identification. These included haematoxylin and eosin, a stain combining periodic acid Schiff with alcian blue $(\mathrm{pH} 2.5)$ to differentiate different types of mucins, and a Grocott's modified Gomori hexamine silver stain to check the possibility that the acellular material might be proteinacious debris associated with Pneumocystis carinii infection.

\section{Electron microscopy}

A $10 \mathrm{ml}$ aliquot of each fresh lavage sample was immediately fixed in glutaraldehyde and prepared for transmission electron microscopy. ${ }^{14}$ Ultrathin sections were double stained with uranyl acetate followed by lead citrate.

\section{Biochemical analysis}

Cells were routinely separated from the lavage samples within 30 minutes of collection by sedimenting by means of low speed centrifugation at $250 \mathrm{~g}$ for 10 minutes at $4^{\circ} \mathrm{C}$. The supernatant fluid containing extracellular components, including lipids, was divided into aliquots and immediately frozen and stored at $-70^{\circ} \mathrm{C}$. To undertake lipid analysis a $10 \mathrm{ml}$ aliquot was thawed and the total lipids extracted in the presence of butylated hydroxytoluene $(10 \mu \mathrm{g}){ }^{15}$ For this the lavage supernatant fluid $(10 \mathrm{ml})$ is mixed with methanol-chloroform ( 25 and $12.5 \mathrm{ml}$ ) to produce a one phase system, then further chloroform $(12.5 \mathrm{ml})$ is added to form a two phase system. The lipids are extracted into the organic phase. The organic phase is then washed by adding distilled water $(12 \mathrm{ml})$ to remove most of the salts present (which could otherwise interfere with the subsequent separation of phospholipids) and then separated. The extracted total lipids were taken down to dryness under reduced pressure at $20^{\circ} \mathrm{C}$ in a rotary evaporator, and then resuspended in chloroform/methanol $(9: 1 \mathrm{v} / \mathrm{v})$ to 40 $\mathrm{mg} \mathrm{lipid} / \mathrm{ml}$ under nitrogen at $-40^{\circ} \mathrm{C}$. The phospholipid profiles in each sample were then identified by means of the improved one dimensional thin layer chromotography system developed by Gilfillan et al. ${ }^{16}$ The lavage extracts were run simultaneously alongside phospholipid standards; the separated phospholipids were visualised with $10 \%$ copper sulphate in $8 \%$ phosphoric acid and charred at $180^{\circ} \mathrm{C}$ for 10 minutes ${ }^{17}$ and then scanned with a reflectance densitometer. The amount of each phospholipid present and its proportion to the total phospholipid content was then calculated for each sample by comparison with the reference standards.

\section{Pneumocystis serum antibody}

Titres of antibody to Pneumocystis carinii in the serum of the patients were determined. ${ }^{18}$

\section{Clinical details}

Clinical details were obtained retrospectively from the patients' records. The patients were managed according to standard clinical protocols. ${ }^{19}$

\section{Results}

\section{LIPOPROTEIN AGGREGATES}

Large acellular globules with basophilic staining by May-Grünwald Giemsa were detected in lavage fluid cytocentrifuge preparations from five of the 718

Table 1 Details of patients and their diagnoses

\begin{tabular}{|c|c|c|c|c|c|c|}
\hline \multirow[b]{2}{*}{$\begin{array}{l}\text { Patient } \\
\text { No }\end{array}$} & \multirow[b]{2}{*}{$\begin{array}{l}\text { Age } \\
(y)\end{array}$} & \multirow[b]{2}{*}{ Sex } & \multicolumn{2}{|l|}{ Diagnosis } & \multirow[b]{2}{*}{ Diagnostic method } & \multirow[b]{2}{*}{ Smoker } \\
\hline & & & Initial & $\begin{array}{l}\text { Reviewed } \\
\text { after lavage }\end{array}$ & & \\
\hline $\begin{array}{l}1 \\
2 \\
3 \\
4 \\
5\end{array}$ & $\begin{array}{l}30 \\
62 \\
72 \\
45 \\
28\end{array}$ & $\begin{array}{l}\mathbf{M} \\
\mathbf{M} \\
\mathbf{F} \\
\mathbf{F} \\
\mathbf{M}\end{array}$ & $\begin{array}{l}\text { CFA } \\
\text { CFA } \\
\text { CFA } \\
\text { Sarcoidosis } \\
\text { Sarcoidosis }\end{array}$ & $\begin{array}{l}\text { CFA } \\
\text { CFA } \\
\text { CFA } \\
\text { Sarcoid } \\
\text { Idiopathic ALP }\end{array}$ & $\begin{array}{l}\text { Open lung biopsy } \\
\text { Clinical } \\
\text { Clinical } \\
\text { Transbronchial lung biopsy } \\
\text { Transbronchial lung biopsy* }\end{array}$ & $\begin{array}{l}\text { No } \\
\text { Ex-smoker } \\
\text { No } \\
\text { No } \\
\text { Yes }\end{array}$ \\
\hline
\end{tabular}

*Previous open lung biopsy was equivocal.

CFA-cryptogenic fibrosing alveolitis; ALP-alveolar lipoproteinosis. 


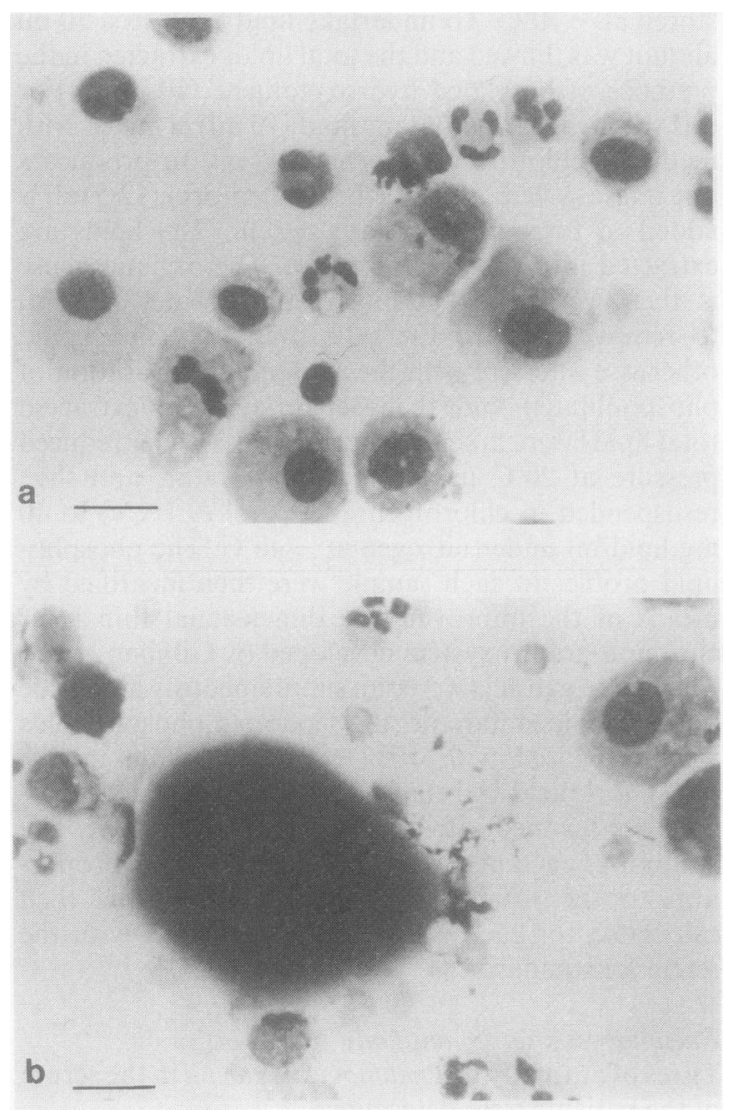

Fig 1 (a) Typical example of the light microscopy appearance of a cytocentrifuge preparation from a patient with cryptogenic fibrosing alveolitis, showing the range of lavage cell types commonly found, including increased numbers of neutrophils, eosinophils, and macrophages, but without lipoprotein aggregates. Scale bar $=25 \mu \mathrm{m}$.

(b) Cytocentrifuge preparation from patient 1 with cryptogenic fibrosing alveolitis showing lipoprotein macroaggregates among the cells. The aggregates are 100$200 \mu \mathrm{m}$ in diameter. Scale bar $=25 \mu \mathrm{m}$.

patients studied. This suggested the presence of aggregates of lipoprotein and that a diagnosis of idiopathic alveolar lipoproteinosis should be considered. The lipoprotein macroaggregates varied from about 100 to $200 \mu \mathrm{m}$ in diameter, and the typical appearance is shown in figure 1 . The total number of lipoprotein macroaggregates in each cytocentrifuge preparation (of $2 \times 10^{5}$ cells) was highest in the two patients whose lavage fluid had been noted to have a milky appearance (patients 4 and 5, with 189 and 500 macroaggregates).

The lipoprotein macroaggregates in the five patients appeared eosinophilic with haematoxylin and eosin, resembling the characteristic histological appearance of the intra-alveolar accumulations in idiopathic alveolar lipoproteinosis. In addition, as in idiopathic $\frac{O}{\omega}$ alveolar lipoproteinosis, the lipoprotein macroag- $\vec{T}$ gregates gave pink staining positive for periodic acid- $\varrho$ Schiff and negative with alcian blue. The Gomori- $\infty$ Grocott silver stain gave negative results, with no $\vec{\circ}$ evidence of $P$ carinii cyst forms.

\section{CLINICAL FEATURES OF THE PATIENTS WITH}

\section{LIPOPROTEIN MACROAGGREGATES}

Table 1 gives the diagnoses of the five patients when $\stackrel{\sim}{\sim}$ aggregates were first observed in lavage fluid and the $\overrightarrow{\vec{O}}$ revised diagnoses after further investigations in the ${ }_{\circ}$ light of the observations on the lavage fluid. Only one ${ }^{3}$ patient (No 5) was rediagnosed as having idiopathic ${ }_{7}$ alveolar lipoproteinosis on the basis of subsequent $\frac{\mathbb{D}}{\circ}$ transbronchial lung biopsy findings, and an atypical history for the initial diagnosis. Clinical symptoms, chest radiographic appearance, and an equivocal $\overrightarrow{0}$ earlier open lung biopsy result had led to the diagnosis 0 of sarcoidosis and treatment with prednisolone for $27^{\circ}$ months. Bronchoalveolar lavage was undertaken because of continued deterioration despite steroid treatment. This patient is now being treated with whole lung lavage and is improved and stable.

The diagnosis in the other four patients was confir- $\stackrel{\square}{\square}$ med as cryptogenic fibrosing alveolitis in three and $\overrightarrow{\vec{O}}$ sarcoidosis in one. The lavage findings and clinical 3 features of these four patients are given in table 2 .

Relationship to lavage cell counts The only consistent finding was that all four patients with lipoprotein macroaggregates had increased percentages of neutro- $\frac{0}{2}$ phils $(>4 \%)$. The percentages of neutrophils did not $\times$ correlate with the numbers of lipoprotein macroag- $\frac{3}{3}$ gregates, and many other patients with interstitial lung disease in our lavage series had increased neutrophils $ᄋ$ without lipoprotein macroaggregates.

Relationship to clinical state All four patients had을 shown progressive deterioration in symptoms despite corticosteroid treatment, and in two patients (Nos 1 . and 2) this had prompted a second lavage. At the time $N$ lipoprotein macroaggregates were detected symptoms $N$ had been present for 6-168 months.

Relationship to treatment All four patients were $\tilde{\omega}$ having prednisolone at the time lipoprotein macroaggregates were detected, and the number of lipoprotein macroaggregates per lavage fluid prepara- $\mathbb{D}$ tion tended to correlate with the length of time that the ? patients had received corticosteroid treatment (Spear- 0 man rank correlation coefficients; $r s=1, p<0.01)$. $\frac{\vec{D}}{\mathbb{D}}$ Relationship to $P$ carinii serum antibody titres There $\frac{\odot}{\mathbb{Q}}$ were raised titres of antibody to $P$ carinii in the serum $\stackrel{\mathcal{D}}{2}$ of all four patients at the time lipoprotein macroaggregates were detected. Antibiotic treatment, $\varnothing$ 
including normal dose co-trimoxazole, was initiated in patient 2 and high dose co-trimoxazole in patient 4 , and both showed some clinical improvement.

\section{ULTRASTRUCTURAL A PPEARANCES OF THE \\ LIPOPROTEIN AGGREGATES}

The ultrastructural appearances of the lipoprotein macroaggregates in the patients with interstitial lung disease are compared with the appearances in typical cases of idiopathic alveolar lipoproteinosis in figure 2 . The macroaggregate from patient 2 appears as a convoluted mass of phospholipid lamellae with regular periodicity, like macroaggregates in idiopathic alveolar lipoproteinosis (fig 2c). Most lamellae formed a parallel pattern, and cross lattice formation was not the predominant form. All four patients had these macroaggregates. By contrast, in typical cases of idiopathic alveolar lipoproteinosis, many small (2-5 $\mu \mathrm{m})$ lamellar bodies of wavy or regular periodicity are found with undifferentiated amorphous debris (fig $2 d$ ). These features were present in patient 5 (table 1), who later was rediagnosed as having idiopathic alveolar lipoproteinosis (fig $2 e$ ).
ANALYSIS OF PHOSPHOLIPID PROFILES IN CELL FREE LAVAGE flUIDS

The phospholipid composition of the cell free lavage fluid from patients with interstitial lung disease with lipoprotein macroaggregates, four patients with classical idiopathic alveolar lipoproteinosis, and 10 control subjects with normal lungs is shown in table 3 . The patients with classical idiopathic alveolar lipoproteinosis had proportionately much less phosphatidylcholine and more lysophosphatidylcholine and sphingomyelin; they also contained less phosphatidylglycerol and phosphatidylethanolamine but more phosphatidylserine and phosphatidylinositol. The patients with interstitial lung disease had significant increases only in phosphatidylserine.

The mean total phospholipid concentration $(\mu \mathrm{g} / \mathrm{ml}$ of lavage fluid) for the four patients with interstitial lung disease was higher than for the controls but, by contrast with the idiopathic alveolar lipoproteinosis cases, this difference was not significant.

\section{Discussion}

This study has shown that care must be taken when

Table 2 Clinical symptoms, lung function, and characteristics of bronchoalveolar lavage (BAL) fluid in patients with cryptogenic fibrosing alveolitis (CFA) and sarcoidosis

\begin{tabular}{|c|c|c|c|c|c|c|c|c|c|}
\hline \multirow[b]{2}{*}{$\begin{array}{l}\text { Patient } \\
\text { No }\end{array}$} & \multirow[b]{2}{*}{$\begin{array}{l}\text { Final } \\
\text { diagnosis }\end{array}$} & \multirow{2}{*}{$\begin{array}{l}\text { Symptoms } \\
\text { (change in } 3 \text { mo } \\
\text { before } B A L)\end{array}$} & \multicolumn{2}{|l|}{ Signs } & \multirow{2}{*}{$\begin{array}{l}\text { Duration } \\
\text { of symptoms } \\
\text { (months) }\end{array}$} & \multicolumn{4}{|c|}{$\begin{array}{l}\text { Lung function at } B A L \\
\text { (\% predicted) }\end{array}$} \\
\hline & & & Clubbing & $\begin{array}{l}\text { Basal } \\
\text { crackles }\end{array}$ & & $F V C$ & Kсо & $T_{L C O}$ & $V_{A}$ \\
\hline 1 & CFA & & & & & & & & \\
\hline 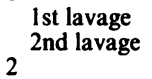 & CFA & $\begin{array}{l}\text { Increasing breathlessness } \\
\text { Increasing breathlessness }\end{array}$ & - & $\begin{array}{l}+ \\
+\end{array}$ & $\begin{array}{r}9 \\
13\end{array}$ & $\begin{array}{l}58 \\
59\end{array}$ & $\begin{array}{l}66 \\
65\end{array}$ & $\begin{array}{l}75 \\
67\end{array}$ & $\begin{array}{l}58 \\
57\end{array}$ \\
\hline $\begin{array}{l}\text { 1st lavage } \\
\text { 2nd lavage }\end{array}$ & CFA & $\begin{array}{l}\text { Cough, breathlessness } \\
\text { Increasing breathlessness } \\
\text { Increasing breathlessness, } \\
\text { cough and sputum }\end{array}$ & $\begin{array}{l}- \\
+\end{array}$ & $\begin{array}{l}+ \\
+ \\
+\end{array}$ & $\begin{array}{r}6 \\
10 \\
67\end{array}$ & $\begin{array}{l}53 \\
65 \\
46\end{array}$ & $\begin{array}{l}73 \\
54 \\
84\end{array}$ & $\begin{array}{l}44 \\
59 \\
63\end{array}$ & $\begin{array}{l}44 \\
61 \\
48\end{array}$ \\
\hline 4 & Sarcoidosis & $\begin{array}{l}\text { Increasing breathlessness, } \\
\text { cough, skin } \\
\text { manifestations }\end{array}$ & + & + & 168 & 48 & 81 & 56 & 44 \\
\hline
\end{tabular}

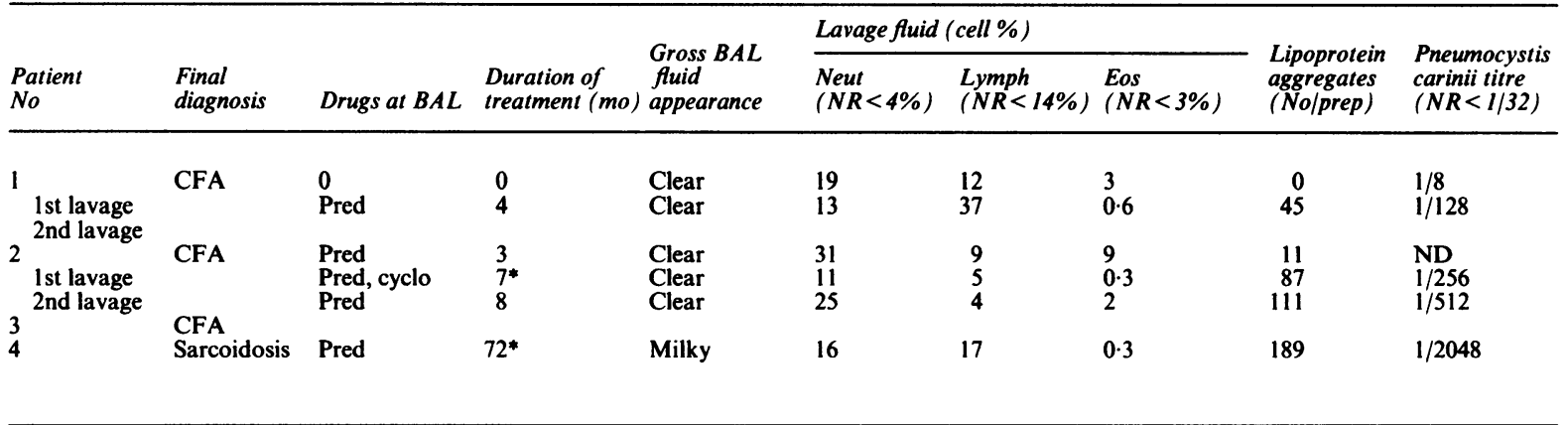

* Recent improvement when normal dose (case 2) or high dose (case 4) co-trimoxazole added.

FVC - forced vital capacity; K Co-transfer coefficient for carbon monoxide; TLco-transfer factor for carbon monoxide; $\mathrm{VA}_{\mathrm{A}}-\mathrm{alveolar}$ volume; Pred-prednisolone; cyclo-cyclophosphamide; Neut—neutrophils; Lymph-lymphocytes; Eos - cosinophils; NR - normal range; ND-not done. 


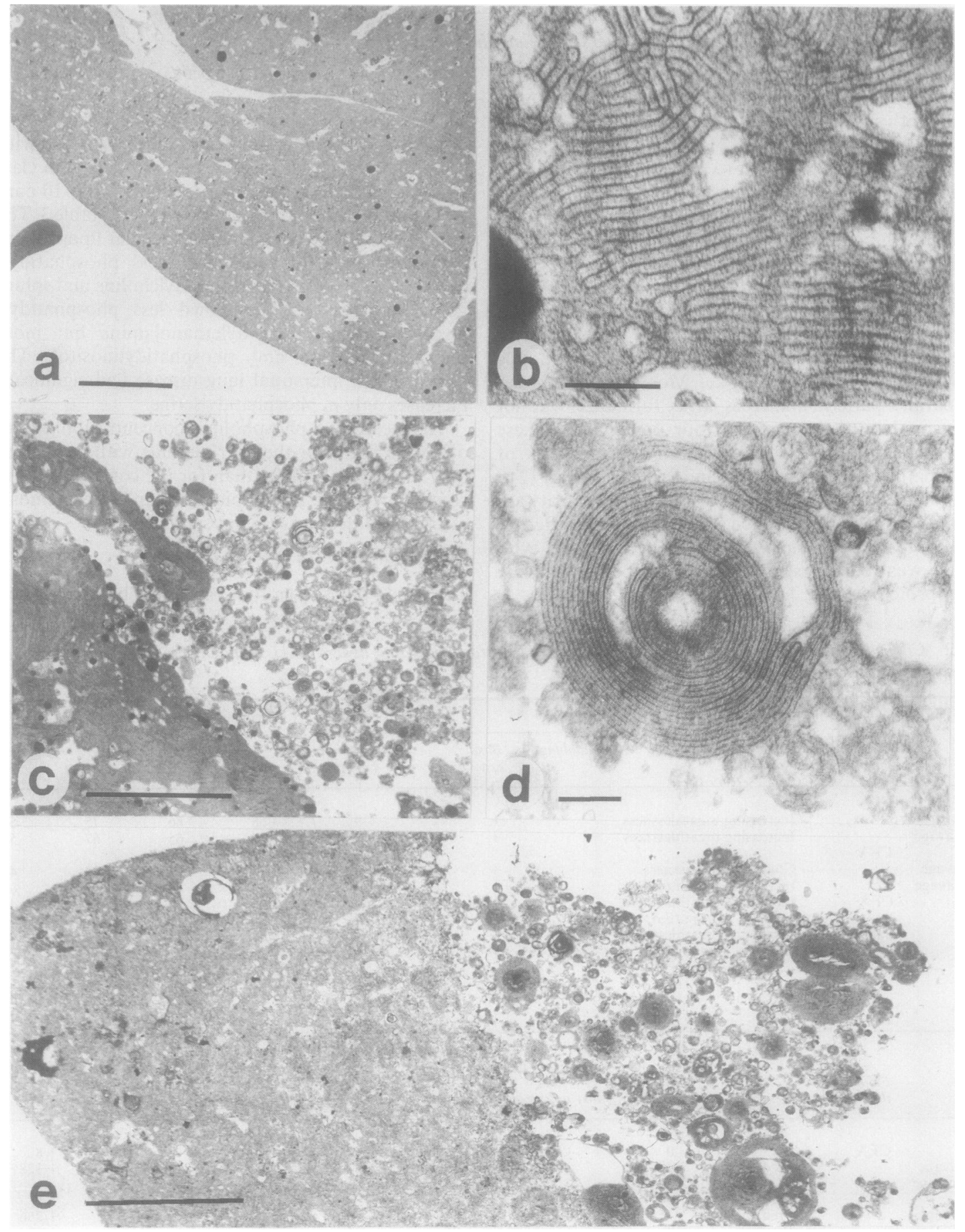

Fig 2 (a) Electron micrograph of lavage material from patient 2 with interstitial lung disease showing a lipoprotein macroaggregate containing small round electron dense structures. An erythrocyte is included in the field for size comparison. Scale bar $=5 \mu \mathrm{m}$. (b) High power detail showing the convoluting parallel phospholipid lamellae of the macroaggregate. Areas of lattice formation (tubular myelin) are occasionally present. Scale bar $=250 \mathrm{~nm}$. (c) Electron micrograph showing therapeutic lavage material from a patient with idiopathic alveolar lipoproteinosis. A lipoprotein macroaggregate is seen as well as a preponderance of small lamellar bodies and amorphous debris. Scale bar $=5 \mu \mathrm{m}$. (d) At high magnification the small lamellar bodies show a regular concentric arrangement of phospholipid lamellae. Miscellaneous membranous debris and amorphous material are present admixed with the lamellar bodies. Scale bar $=250 \mathrm{~nm}$. (e) Lavage material from patient 5 showing both a lipoprotein macroaggregate and a large number of small lamellar bodies, similar to those from confirmed cases of idiopathic alveolar lipoproteinosis. Scale bar $=5 \mu \mathrm{m}$. 
Table 3 Phospholipid composition in bronchoalveolar lavage fluid (mean (SD) percentages of total phospholipid content) from patients with idiopathic lipoproteinosis ( $A L P)$ and interstitial lung disease (ILD) with lipoprotein macroaggregates (LMA)

\begin{tabular}{|c|c|c|c|}
\hline Phospholipid & $\begin{array}{l}\text { Controls } \\
(n=10)\end{array}$ & $\begin{array}{l}\text { Idiopathic } \\
A L P \\
(n=4)\end{array}$ & $\begin{array}{l}\text { ILD with } \\
L M A \\
(n=4)\end{array}$ \\
\hline $\begin{array}{l}\text { Lysophosphatidylcholine } \\
\text { Sphingomyelin } \\
\text { Phosphatidylcholine } \\
\text { Phosphatidylinositol } \\
\text { Phosphatidylserine } \\
\text { Phosphatidylethanolamine } \\
\text { Phosphatidylglycerol }\end{array}$ & $\begin{array}{l}0 \\
5 \cdot 4(5 \cdot 4) \\
53 \cdot 5(6 \cdot 3) \\
0 \\
1 \cdot 5(3 \cdot 1) \\
19 \cdot 3(1 \cdot 6) \\
16 \cdot 6(3 \cdot 8)\end{array}$ & $\begin{array}{r}12 \cdot 8(10 \cdot 7)^{*} \\
28 \cdot 4(10 \cdot 2)^{* * *} \\
24 \cdot 3(3 \cdot 8)^{* * *} \\
7 \cdot 7(5 \cdot 1)^{* * *} \\
8 \cdot 4(1 \cdot 6)^{* * *} \\
12 \cdot 0(3 \cdot 7)^{* * *} \\
5 \cdot 2(3 \cdot 1)^{* * *}\end{array}$ & $\begin{array}{l}0 \\
4 \cdot 6(3 \cdot 8) \dagger \\
50 \cdot 1(13 \cdot 2) \dagger \\
0 \dagger \\
10 \cdot 4(3 \cdot 6)^{* *} \\
18 \cdot 2(7 \cdot 9) \\
14 \cdot 3(4 \cdot 9) \dagger\end{array}$ \\
\hline Total phospholipid $(\mu \mathrm{g} / \mathrm{ml})$ & $15.9(8 \cdot 2)$ & $39.6(31.6)^{* *}$ & $29.8(16 \cdot 3)$ \\
\hline
\end{tabular}

${ }^{*} p<0.05,{ }^{* *} p<0.02,{ }^{* * *} p<0.002$ in the comparison with controls (Mann-Whitney U test); $\nmid p<0.05$ in the comparison with classic cases of idiopathic ALP (Mann-Whitney U test).

large lipoprotein aggregates are detected in the routine cytological investigation of lavage samples, to distinguish idiopathic from other causes of alveolar lipoproteinosis. Lipoprotein macroaggregates occasionally occur in lavage fluid from patients with interstitial lung diseases. None of the patients had a history of exposure to silica dust, a recognised cause of secondary alveolar lipoproteinosis. ${ }^{20}$ Despite the cytological similarity to cases of idiopathic alveolar lipoproteinosis, we observed ultrastructural and biochemical differences, suggesting that different mechanisms are at work. Our demonstration that in cases of idiopathic alveolar lipoproteinosis many small lamellar bodies and amorphous debris are present, in addition to large lipoprotein aggregates, is in keeping with previous reports on ultrastructure in cases of classic idiopathic alveolar lipoproteinosis; ${ }^{21} 22$ most of the material in our cases of interstitial lung disease was in the form of macroaggregates. The reasons for the development of lipoprotein macroaggregates in occasional patients with interstitial lung disease, the pathognomonic consequences, and therapeutic implications are not clear.

Biochemically, the patients with interstitial lung disease who had lipoprotein macroaggregates showed an increased proportion of phosphatidylserine in their cell free lavage fluid as in idiopathic alveolar lipoproteinosis, but they did not show the other changes in the insoluble pulmonary secretions associated with this disorder, which are thought to result from phospholipase A2 activity. ${ }^{23-25}$

Discussion of possible clinical correlations for such a rare feature can be only speculative, but one suggestion is that the lipoprotein macroaggregates may be a secondary effect of corticosteroid treatment. Glucocorticoids enhance the synthesis of pulmonary surfactant ${ }^{26}$ - hence the use of betamethasone during pregnancy to reduce the risk of respiratory distress syndrome of the newborn..$^{27}$ The reason why lipoprotein aggregates are rarely detected microscopically in lavage fluid in conditions where corticosteroids are used frequently is not known, but biochemical changes may be more common. There is evidence that changes in the proportions of phospholipids in lavage fluids from patients with cryptogenic fibrosing alveolitis may reflect corticosteroid response. ${ }^{29}$

The increased $P$ carinii serum antibody titres in the patients with interstitial lung disease who had lipoprotein macroaggregates might suggest that they had developed secondary opportunist infection as a consequence of immunosuppression; but no morphological evidence of the presence of pneumocystis trophozoite forms was obtained. Nevertheless, evidence of $\boldsymbol{P}$ carinii is often difficult to establish, and some improvement was achieved in two of the patients after treatment with co-trimoxazole. The link between these observations in such a small group of patients needs to be interpreted with caution, but there has been one report of alveolar lipoproteinosis in eight patients with various haematopoietic malignant diseases, associated with immunosuppression and in all but one of the patients an opportunistic infection. ${ }^{30}$

In conclusion, the presence of large lipoprotein aggregates in lavage fluid samples may indicate the presence of idiopathic alveolar lipoproteinosis, but it may reflect secondary alveolar lipoproteinosis in patients with interstitial lung diseases.

We thank Professor Margaret Turner-Warwick and other chest physicians at the Brompton Hospital who have referred patients for lavage; Dr John Collins for help with bronchoscopy; Dr Margaret Branthwaite for samples of fluid from therapeutic lavage; Dr Beryl Jameson (Royal Marsden Hospital) for undertaking the Pneumocystis carinii serum antibody measurements; and Miss Katherine Heath for typing the manuscript. We are also grateful to the Chest, Heart, and Stroke Association and Boehringer Ingelheim for their support.

\section{References}

1 Haslam PL. Bronchoalveolar lavage. Sem Respir Med 1984;6:55-70.

2 Daniele RP, Elias JA, Epstein PE, Rossman MD. Bronchoalveolar lavage: role in the pathogenesis, diagnosis, and management of interstitial lung disease. Ann of Intern Med 1985;102:93-108.

3 Crystal RG, Reynolds HY, Kalica AR. Bronchoalveolar lavage. The report of an international conference. Chest 1986;89:122-31.

4 Martin RJ, Coalson JJ, Rogers RM, Horton FO, Manous LE. Pulmonary alveolar proteinosis: the diagnosis 
by segmental lavage. Am Rev Respir Dis 1980;121: 819-25.

5 Rosen SH, Castleman B, Liebow AA. Pulmonary alveolar proteinosis. $N$ Engl J Med 1958;258:1123-42.

6 Ramirez J, Schwartz B, Dowell AR, Lee SD. Biochemical composition of human pulmonary washings. Arch Intern Med 1971;127:395-401.

7 Ito M, Takeuchi N, Ogura T, et al. Pulmonary alveolar proteinosis: Analysis of pulmonary washings. $\mathrm{Br} \mathrm{J} \mathrm{Dis}$ Chest, 1978;72:313-20.

8 Davidson JM, MacLeod WM. Pulmonary alveolar proteinosis. Br J Dis Chest 1969;63:13-28.

9 Crofton J, Douglas A. Pulmonary alveolar proteinosis. Respiratory diseases. 3rd ed. Oxford: Blackwell Scientific Publications, 1981:758-63.

10 Du Bois RM, McAllister WAC, Branthwaite MA. Alveolar proteinosis: diagnosis and treatment over a ten year period. Thorax 1983;38:360-3.

11 Selecky PA, Wasserman K, Benfield JR, Lippman M. The clinical and physiological effect of whole lung lavage in pulmonary alveolar proteinosis: a ten year experience. Ann Thorac Surg 1977;24:451-61.

12 Dhillon DP, Haslam PL, Townsend PJ, Primett Z, Collins JV, Turner-Warwick $M$. Bronchoalveolar lavage in patients with interstitial lung diseases: side effects and factors affecting fluid recovery. Eur $J$ Respir Dis 1986;68:342-50.

13 Haslam PL, Turton CWG, Lukoszek A, Salsbury AJ, Collins JV, Turner-Warwick M. Bronchoalveolar lavage fluid cell counts in cryptogenic fibrosing alveolitis and their relation to therapy. Thorax 1980;35:328-39.

14 Haslam PL, Dewar A, Butchers P, Primett ZS, NewmanTaylor A, Turner-Warwick M. Mast cells in bronchoalveolar lavage samples from patients with extrinsic allergic alveolitis. Am Rev Respir Dis 1987;135:35-47.

15 Bligh EG, Dyer WJ. A rapid method of total lipid extraction and purification. Can J Biochem Physiol 1959;37:911-7.

16 Gilfillan AM, Chu AJ, Smart DA, Rooney SA. Single plate separation of lung phospholipids including disaturated phosphatidylcholine. J Lipid Res 1983; 24:1651-6.

17 Bitman J, Wood DL. An improved copper reagent for quantitative densitometric thin-layer chromatography of lipids. J Liq Chromatog 1982;5:1155-62.
18 Shepherd V, Jameson B, Knowles GK. Pneumocystis carinii pneumonitis: a serological study. J Clin Pathol 1979;32:773-7.

19 Turner-Warwick M. Interstitial lung disease: approaches to therapy. Sem Respir Med 1984;6:92-102.

20 Parkes WR. Alveolar silico-lipoproteinosis. Occupational lung disorders. 2nd ed. London: Butterworths, 1982: कs 166-70.

21 Heppleston AG, Young AE. Alveolar lipoproteinosis: an ultrastructural comparison of the experimental and $\vec{\omega}$ human forms. J Pathol 1972;107:107-17.

22 Hook GER, Filmore LB, Talley FA. Multilamellated $\vec{x}$ structures from the lungs of patients with pulmonary alveolar proteinosis. Lab Invest 1984;50:711-25.

23 Sahu S, DiAugustine RP, Lynn WS. Lipids found in ? pulmonary lavage of patients with alveolar proteinosis $\vec{A}$ and in rabbit lung lamellar organelles. Am Rev Respir Dis; 1976;114:177-85.

24 Sahu S, Lynn WS. Phospholipase A in pulmonary secretions of patients with alveolar proteinosis. Biochim $\mathbb{T}$ Biophys Acta 1977;487:354-60.

25 Sahu S, Lynn WS. Characterization of phospholipase A from pulmonary secretions of patients with alveolar 2 proteinosis. Biochem Biophys Acta 1977;489:307-17.

26 Gross I, Ballard PL, Ballard RA, Jones CR, Wilson CM. D Corticosteroid stimulation of phosphatidylcholine synthesis in cultured fetal rabbit lung: evidence for de novo protein synthesis mediated by glucocorticoid receptors. Endocrinology 1983;112:829-37.

27 Liggins GC, Howie RN. A controlled trial of antepartum glucocorticoid treatment for prevention of the res- $\mathbb{D}$ piratory distress syndrome in premature infants. Pediatrics 1972;50:515-25.

28 Collaborative Group on Antenatal Steroid Therapy. Effect of antenatal dexamethasone administration on the prevention of respiratory distress syndrome. $A m J$ Obstet Gynecol 1981;141:276-86.

29 Hughes DA, Haslam PL. Phosphatidylglycerol levels in 을 bronchoalveolar lavage fluid from patients with cryptogenic fibrosing alveolitis in relation to response to prednisolone (abstract). Am Rev Respir Dis 1987; 135:A30.

30 Bedrossian CWM, Luna MA, Conklin RH, Miller WC. Alveolar proteinosis as a consequence of immunosuppression. A hypothesis based on clinical and pathological observations. Hum Pathol 1980;11:527-35. 